Uniwersytet PrzyrodniczoHumanistyczny w Siedlcach

Siedlce University of Natural Sciences and Humanities

https://bazawiedzy.uph.edu.pl

\begin{tabular}{|l|l|}
\hline Publikacja / Publication & $\begin{array}{l}\text { Motility activity, slime production, biofilm formation and genetic typing by ERIC- } \\
\text { PCR for Pseudomonas aeruginosa strains isolated from bovine and other sources } \\
\text { (human and environment ), } \\
\text { Wolska Marzena Katarzyna, Szweda Piotr, Lada Karolina, Rytel Elżbieta, Gucwa } \\
\text { Katarzyna, Kot Barbara, Piechota Małgorzata }\end{array}$ \\
\hline $\begin{array}{l}\text { Adres publikacji w Repozytorium URL } \\
\text { / Publication address in Repository }\end{array}$ & https://bazawiedzy.uph.edu.pl/info/article/UPHa934cf3de52040a3a3caf49f559ffcd7/ \\
\hline $\begin{array}{l}\text { Data opublikowania w Repozytorium / } \\
\text { Deposited in Repository on }\end{array}$ & 22 paź 2021 \\
\hline Rodzaj licencji / Type of licence & Attribution CC BY O \\
\hline Cytuj tę wersję / Cite this version & $\begin{array}{l}\text { Wolska Marzena Katarzyna, Szweda Piotr, Lada Karolina, Rytel Elżbieta, Gucwa } \\
\text { Katarzyna, Kot Barbara, Piechota Małgorzata: Motility activity, slime production, } \\
\text { biofilm formation and genetic typing by ERIC-PCR for Pseudomonas aeruginosa } \\
\text { strains isolated from bovine and other sources (human and environment ), Polish } \\
\text { Journal of Veterinary Sciences, vol. 17, no. 2, 2014, pp. 321-329 }\end{array}$ \\
\hline
\end{tabular}




\title{
Motility activity, slime production, biofilm formation and genetic typing by ERIC-PCR for Pseudomonas aeruginosa strains isolated from bovine and other sources (human and environment)
}

\author{
K. Wolska ${ }^{1}$, P. Szweda ${ }^{2}$, K. Lada ${ }^{1}$, E. Rytel ${ }^{1}$, K. Gucwa ${ }^{2}$, \\ B. Kot ${ }^{1}$, M. Piechota ${ }^{1}$ \\ ${ }^{1}$ Department of Microbiology, Nature Faculty, University of Natural Sciences and Humanities in Siedlce, \\ Prusa 12, 08-110 Siedlce, Poland \\ ${ }^{2}$ Department of Pharmaceutical Technology and Biochemistry, Faculty of Chemistry, \\ Gdansk University of Technology, G. Narutowicza 11/12, 80-233 Gdansk, Poland
}

\begin{abstract}
The molecular-typing strategy, ERIC-PCR was used in an attempt to determine the genomic relationship of $28 P$. aeruginosa strains isolated from faeces of healthy bovine, bovine mastitis and from faeces of hospital patients as well as from environment. ERIC-PCR fingerprinting revealed large molecular differentiation within this group of isolates. Twenty two out of 28 strains tested generated unique patterns of DNA bands and only three genotypes consisted of two isolates each were identified.

We also tested the $P$. aeruginosa isolates for their ability to form a biofilm on abiotic surfaces including polyvinylchloride and polystyrene. Different biofilm-forming abilities were demonstrated among strains; however, most of them (64.3\%) showed moderate-biofilm forming ability. The strains with increased swimming and twitching motility displayed elevated biofilm formation. However, a negative correlation was found between slime and initial biofilm production. On the basis of the results obtained, we suggest that there are no major differences in phenotypic properties between $P$. aeruginosa strains isolated from different sources.
\end{abstract}

Key words: Pseudomonas aeruginosa, ERIC-PCR, biofilm, slime, twitching motility, swimming motility 


\section{Inntroduction}

Pseudomonas aeruginosa is a common inhabitant of soil, water, plants and other natural environments. It can multiply in almost any moist environment and has minimal nutritional requirements. Moreover it is tolerant to a wide variety of physical conditions. Consequently, $P$. aeruginosa can be found in the hospital environment and reservoirs such as sinks, floors, bath, bath soaps and also medical equipment. It is considered an opportunistic pathogen as it causes infection in immunodepressed subjects (Head and $\mathrm{Yu}$ 2004). $P$. aeruginosa has also been identified as an animal pathogen and as the occasional cause of bovine mastitis (McLennan et al. 1997, Malinowski et al. 2006). Mastitis caused by $P$. aeruginosa are frequently associated with the use of contaminated wash water, teat dips, or multidose mastitis antibiotic preparations (Erskine et al. 1987, Daly et al. 1999).

Further, evidence has suggested that there are no major differences in virulence between clinical and environmental isolates (Woods et al. 1997). In nature and clinical settings, $P$. aeruginosa are frequently found in surface-attached multicellular communities called biofilms. Forming of the biofilm is a highly regulated process that proceeds through a number of distinct stages. These stages can be divided into the initial attachment, microcolony formation, maturation and finally dispersion, which releases planctonic cells back into the environment (Sauer et al. 2002). The first stage of biofilm development involves initial contact, which is followed by irreversible attachment of bacteria to the surface. This process involves a multitude of different adhesins and extracellular appendages, the requirement of which is likely to depend on the surface and the environmental conditions. (O'Toole and Kolter 1998, Glessner et al. 1999).

In $P$. aeruginosa, the flagellum is recognized as a central component in the biofilm process. It provides the mobility needed to actively approach a surface. The next important factor in surface attachment and motility of $P$. aeruginos $a$ are type IV pili. They are located at the pole of the cells and are involved in twitching motility, which is an unique type of movement across semi-solid surfaces. The movement results from the extension, tethering, and retraction of the pilus structure (O'Toole and Kolter 1998, Deziel at al. 2001, Skerker and Berg 2001). After surface colonization, the bacteria begin to communicate with one another in the process called "quorum sensing" and these signs guide the formation of microcolonies that will develop into mushroom-like pillars and give the mature biofilm an unique structure (Klausen et al. 2003, Kumar et al. 2009). Maturation of biofilms involves production of the extracellular matrix, the al- ginate polysaccharide. Alginate production was found to be a hallmark of $P$. aeruginosa chronic infection in the lungs of cystic fibrosis (CF) patients (Singh et al. 2000). The relationship between alginate production and biofilm formation is unclear, since alginate is not essential for biofilm formation in vitro. However, alginate shapes the structure of biofilms and protects the bacteria from the host immune response and from antibiotics and biocides (Hentzer et al. 2001).

PCR-based genotyping methods have played an important role in bacterial typing schemes (Wolska and Szweda 2012). One of the PCR-based methods, is Rep-PCR. This method is used for typing purposes of repetitive DNA elements, especially the 124-127 bp enterobacterial repetitive intergenic consensus (ERIC) (Versalovic et al. 1991). They contain a highly conserved central inverted repeat located in extragenic regions (Houlton et al. 1991). The position of ERIC elements in bacterial genomes varies between different species and has been used as a genetic marker to characterize isolates within a bacterial species (Versalovic et al. 1991).

To date, there have been no reports in the literature comparing the clinical and environmental $P$. aeruginosa strains, through employment ERIC sequence. Therefore, the aim of this study was to examine the genetic relatedness of $P$. aeruginosa isolated from the following sources: faeces of healthy bovine, bovine mastitis and bovine environment as well as strains isolated from the hospital in Siedlce (Poland), through employment of ERIC-PCR and to evaluate the phenotypic properties of these strains such as swimming and twitching motility activity, slime production and biofilm formation.

\section{Materials and Methods}

\section{Bacterial strains}

A total of 28 strains of $P$. aeruginosa were originally isolated from a variety of sources. Fifteen isolates were obtained from faeces of 400 (3.75\%) healthy bovine in 9 different dairy herds of the east-north region of Poland. Three bovine environmental strains were isolated from litter (1 and 2 isolates) and straw (isolate 14).

In the first farm two following strains were obtained: 1 and 17, in the second farm -5 strains $(2,7,8$, $9,21)$, the third one - three strains $(3,6,13)$, the fourth one - three strains $(5,10,12)$, the fifth one - two strains $(14,20)$, the sixth one - one strain (4), seventh - without isolation strains, the eigth one - one strain (16) and in the last farm - one strain (18). Faeces and environmental cultures were done on 
blood agar plates and MacConkey agar plates (Difco, USA).

A selection of 10 control P. aeruginosa organisms were obtained from the Veterinary Laboratory and Depertment of Medical Microbiology at the Municipal Hospital in Siedlce for comparison. These controls included $P$. aeruginosa isolated from mastitis milk samples $(\mathrm{n}=4)$ and isolates from faeces $(\mathrm{n}=5)$ of patients with a variety of clinical cases and $P$. aeruginosa isolated from hospital sink $(\mathrm{n}=1)$. The reference strains of $P$. aeruginosa NCTC 6749 and ATCC 27853 were also investigated.

All isolates were identified phenotypically employing a combination of conventional identification methods (e.g. oxidase, production of green pigment, characteristic odor, growth at $42^{\circ} \mathrm{C}$ ), as well as the API identification scheme (API 20NE) (bioMerieux, France). We also identified $P$. aeruginosa by PCR amplification of fragment of gene coding for 16S rRNA (Kingsford and Raadsma 1995). All isolates resulted in a positive reaction. Stock cultures were stored in triptic soy broth (TSB, Difco, USA) containing $20 \%$ $(\mathrm{v} / \mathrm{v})$ glycerol at $-80^{\circ} \mathrm{C}$.

\section{DNA extraction}

Isolates were grown in TSB at $37^{\circ} \mathrm{C}$ for $24 \mathrm{~h}$ and DNA was extracted by using the Genomic DNA Pre Plus (A\&A Biotechnology, Poland).

\section{PCR procedures}

The two oligonucleotide primers were pairs used to amplify the regions in the bacterial genome positioned between the ERIC sequences. The sequences were: Primer $1 ; 5, \quad$ - CACTTAGGGGTCCTCGAATGTA - 3'; Primer 2; 5' - AAGTAAGTGACTGGGGTGAGCG - 3' (Versalovic et al. 1991). The PCR reaction mixtures contained: $10 \mu \mathrm{l}$ of 2 x PCR Master Mix High GC containing optimized composition of Taq DNA polymerase, PCR reaction buffer and mixture of dNTPs (A\&A Biotechnology, Poland), $1 \mu \mathrm{l}$ of each of the two required primer solutions $(10 \mu \mathrm{M}), 1 \mu \mathrm{l}$ of DNA solution (prepared as described above) and deionized sterile water to complete the mixture volume to $20 \mu$ l.

A thin layer of paraffin oil was added to prevent evaporation. The DNA amplification was done in a thermal cycler (Biometra T-Gradient, Goettingen, Germany) using the following PCR cycles: the first denaturation step of 4 minutes at $94^{\circ} \mathrm{C}$, followed by 35 cycles of denaturation $\left(0.5 \mathrm{~min}\right.$ at $\left.94^{\circ} \mathrm{C}\right)$, annealing $\left(0.5 \mathrm{~min}\right.$ at $\left.52^{\circ} \mathrm{C}\right)$ and extension for $1 \mathrm{~min}$ at $72^{\circ} \mathrm{C}$, with the exception of the last cycle, which had a final extension time of $10 \mathrm{~min}$. Amplifications were performed twice to confirm consistency of the method. The PCR products obtained were separated on $2 \%$ agarose for $60 \mathrm{~min}$ at $110 \mathrm{~V}$ and compared with Gene Ruler $100 \mathrm{bp}$ or $1 \mathrm{~kb}$ ladder (Thermo Scientific).

All data analysis were performed using the computer software Unistat for Windows. Euclidean distance was calculated and compared to evaluate similarity among strains through the use of BIOGENE software.

\section{Biofilm assay to microtiter plates}

The biofilm formation protocol was adapted from that of O'Toole and Kolter (1998). Briefly, $P$. aeruginosa overnight culture was diluted 1:100 in fresh TSB medium (Difco, USA), dispensed $(200 \mu \mathrm{l})$ to wells of a 96-well polystyrene microtiter plate (Sigma-Aldrich, USA) and grown for $24 \mathrm{~h}$ at $37^{\circ} \mathrm{C}$ (unless otherwise noted) with no aeration. Wells were stained with $200 \mu \mathrm{l}$ of $1 \%$ crystal violet (CV) for 15 min at room temperature. Stain was discarded, and the plate was rinsed three times with phosphate buffer saline (PBS pH 7.2) and allowed to dry. Stained biofilm was solubilized with $200 \mu \mathrm{l}$ of $95 \%$ ethanol for $10 \mathrm{~min}$ and read according to the optical density at $450 \mathrm{~nm}\left(\mathrm{OD}_{450}\right)$. Each assay was performed in triplicate and repeated 3 times. The following values were assigned for biofilm determination: $\mathrm{OD}_{450}=0.050$, non-biofilm forming; $0.050<\mathrm{OD}_{450} \leq 0.1$, weak; 0.1 $<\mathrm{OD}_{450} \leq 0.15$, medium; $0.15<\mathrm{OD}_{450}$, strong.

\section{Biofilm assay to Tiemann catheter}

Prosser et al. (1987) developed a simple method to produce biofilm in vitro on catheter pieces. Sterile Tiemann's polyvinylchloride (PVC) catheter pieces of $1 \mathrm{~cm}$ were cut from the tubing (Maersk Medical, USA) and placed into Petri dishes $(3 \mathrm{~cm})$ containing $5 \mathrm{ml}$ of bacterial suspension (overnight culture of $P$. aeruginosa - TSA, diluted 1:100 in TSB). Biofilm was allowed to develop under stationary conditions for 3 days by regularly changing the catheter piece to fresh medium after every $24 \mathrm{~h}$. Each day catheter pieces in duplicate were removed and were placed in separate Petri dishes, rinsed thrice with PBS and transferred to the new Petri dishes containing $5 \mathrm{ml}$ of fresh TSB. The last time, catheter pieces were washed again in PBS and transferred to Petri dishes with fresh TSB broth and 1 drop of 1\% 2,3,5-triphenyltetrazolium chloride in PBS (TTC, Sigma-Aldrich, USA). The presence of red stained bacterial biofilm 


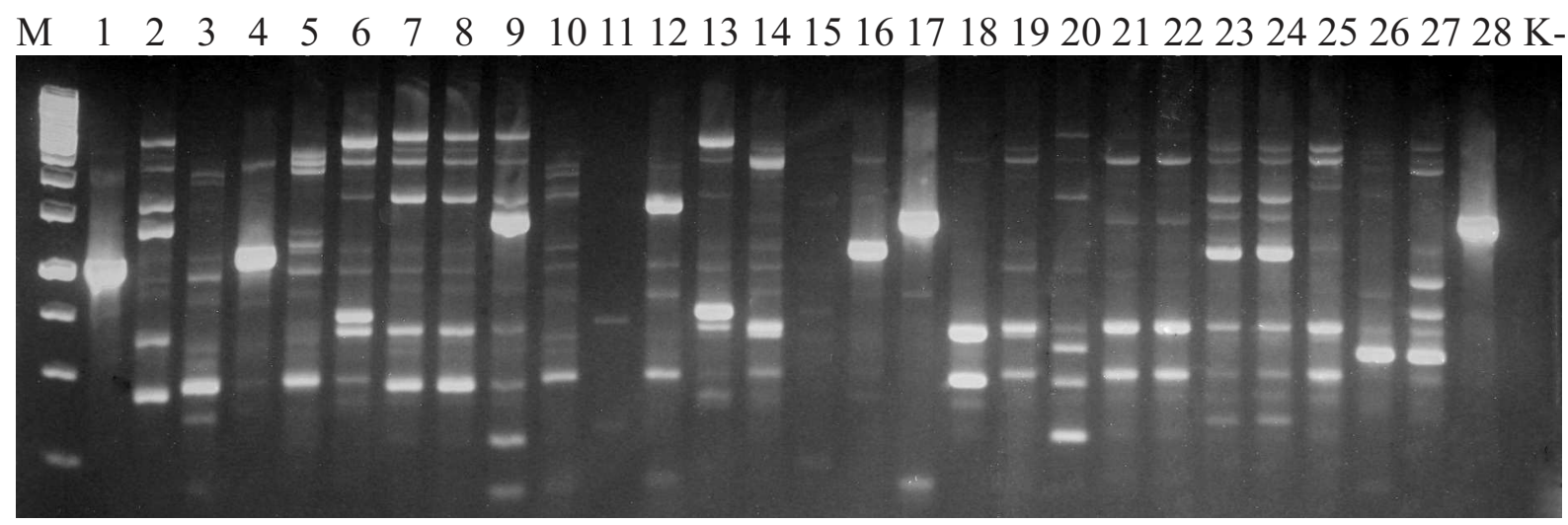

Fig. 1. ERIC-PCR fingerprint of P. aeruginosa strains. Lane M; molecular weigh marker (1000 bp); lane K; negative control; lane 1-28; $P$. aeruginosa strains isolated from faeces of healthy bovine $(3,4,5,6,7,8,9,10,12,13,16,17,18,20,21)$, bovine mastitis $(11,19,22,28)$, bovine environment $(1,2,14)$, faeces of hospital patients $(23,24,25,26,27)$ and hospital sink (15).

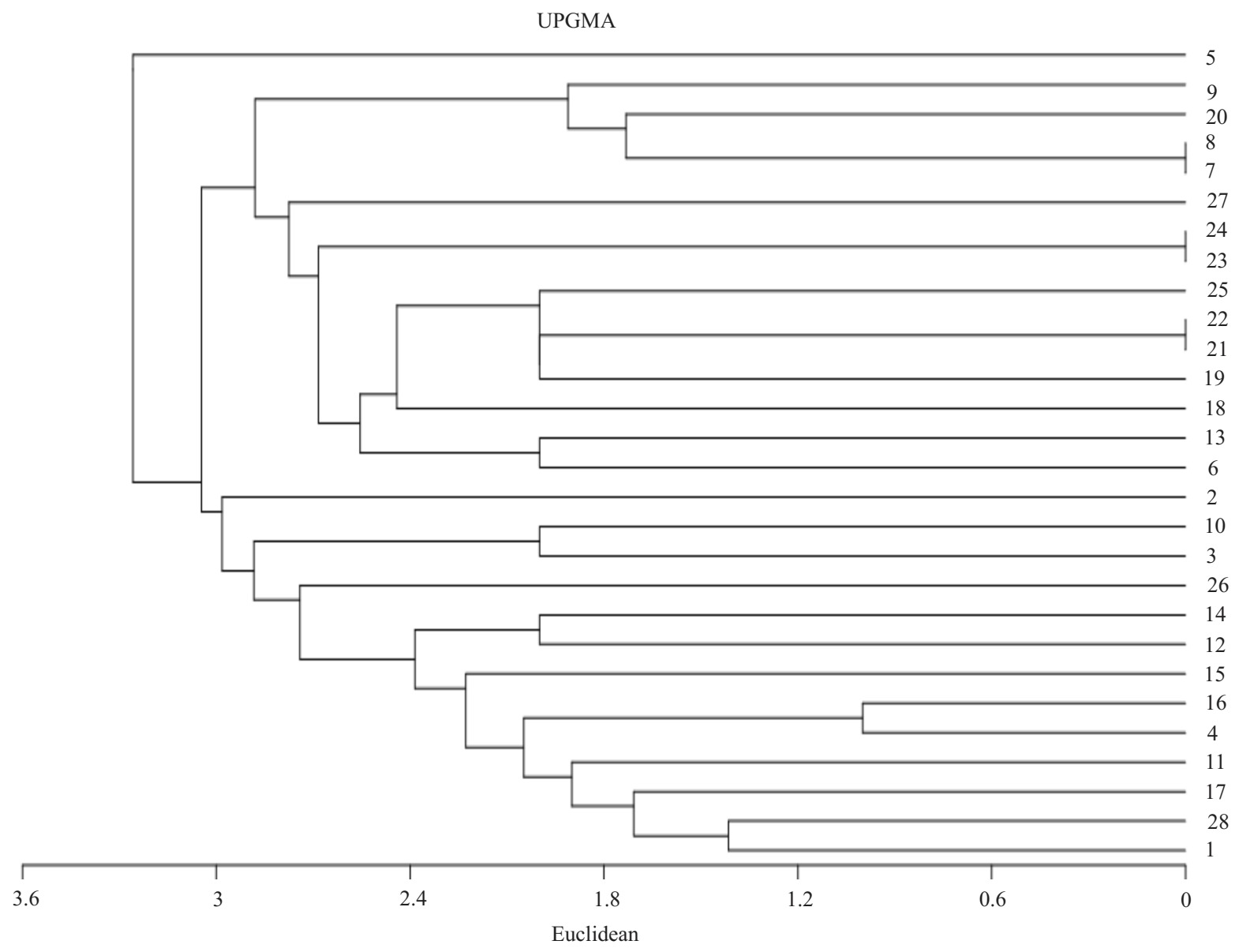

Fig. 2. The dendrogram indicating the genetic relatedness of the $P$. aeruginosa strains.

(reduction by live bacteria of colorless TTC to the red insoluble formazan crystals) was examined after 1,2, 5 and $24 \mathrm{~h}$ of incubation at $37^{\circ} \mathrm{C}$. Following categories of biofilm were determined: the complete absence of catheter color, non-biofilm producting; light spot color of the catheter surface after 1,2, 5 hours, and additionally pink medium color after $24 \mathrm{~h}$ of incuba- tion, weak; redness of the surface and the interior part of the catheter and the red color of medium after 24 $\mathrm{h}$ of incubation (after $5 \mathrm{~h}$ - pink medium color), medium; redness of the whole surface and the interior of the catheter and the deep of medium after $24 \mathrm{~h}$ of incubation (after $5 \mathrm{~h}-$ red medium color), strong. All experiments were performed in triplicate. 


\section{Twitching motility assay}

Cells from fresh culture plates were stab-inoculated with a toothpick a thin (approximately $3 \mathrm{~mm}$ ) Luria-Bertani (LB) agar layer (1.0\% agar) (Difco, USA) to the bottom of the Petri dish. After incubation for 24 at $30^{\circ} \mathrm{C}$, a hazy zone of growth at the interface between the agar and the Petri dish surface was observed (Deziel et al. 2001).

\section{Swimming motility assay}

Tryptone swim plates $(1 \%$ tryptone, $0.5 \% \mathrm{NaCl}$, $0.3 \%$ agar) (Difco, USA) were inoculated with a sterile toothpick and incubated for $24 \mathrm{~h}$ at $26^{\circ} \mathrm{C}$. Motility was then assessed qualitatively by examining the circular turbid zone formed by the bacterial cells migrating away from the point of inoculation (Deziel et al. 2001).

All motility experiments were performed in triplicate.

\section{Slime production}

The procedure was made as described by Christensen et al. (1982). Two to three colonies of the isolates were inoculated into $5 \mathrm{ml}$ of TS broth in a plastic white tube and incubated statically for $24 \mathrm{~h}$ at $37^{\circ} \mathrm{C}$. The contents of the tubes were removed and then stained with $1 \%$ safranin. An adherent film on the surface of the glass tube was considered as evidence of slime formation. The absence of a film or the mere presence of a ring at the liquid-air interface was interpreted as a negative result (-). In the study, positive results were recorded as strong $(+++)$, moderate $(++)$, weak $(+)$. Each test was interpreted by three different observers.

\section{Statistical analysis}

Comparison of biofilm formation with swimming and twitching motility activity as well as slime production was made using the ratio of correlation $\left(\mathrm{r}_{\mathrm{xy}}\right)$. The $\mathrm{p}$ values of $<0.05$ were considered significant.

\section{Results}

\section{ERIC-PCR}

ERIC-PCR patterns were detected in each sample (Fig. 1). The genetic patterns were consisted of one to
10 bands. The average amplicons per gel lane was 6 . The size of generated PCR products varied mainly between 200 and $3000 \mathrm{bp}$ and the most frequently found products of PCR amplification were the following: about $600 \mathrm{bp}$ and $2500 \mathrm{bp}$. ERIC-PCR demonstrated a high discriminatory ability, only three genotypes consisting of two isolates were distinguished (strains with numbers: 7 and 8, 21 and 22, 23 and 24, respectively). The first genotype consisted of the strains isolated from faeces of healthy bovine in the same farm. The second one was represented by the strains obtained from healthy and sick bovine. And the last one consisted of the pair of strains isolated from humans. The other 22 isolates generated unique patterns of amplified DNA fragments. (Fig. 1,2).

\section{Biofilm production}

Next, all isolates were tested for biofilm-forming ability using an adaptation of a polystyrene 96-well microtiter dish method. The strains ATCC 27853 and NCTC 6749 were included in every data to determine biofilm formation. A significant variation in biofilm formation was found among all isolates tested (A $=0.080$ to 0.217 , the average $\mathrm{A}=0.126$ ) (Table 1 ). The majority of these isolates $(18 / 28 ; 64.3 \%)$ formed medium-strength biofilms (the average $\mathrm{A}=0.127$ ) like the controls (Table 1). Only 10/28 (35.7\%) of the samples varied in relation to ATCC27853 and NCTC6749. Four (14.3\%) isolates among them two from faeces of healthy bovine, one strain isolated from bovine environment and one strain obtained from faeces of hospital patients, showed increased amounts of biofilm compared with controls. And only six $(21.4 \%)$ of the samples formed less biofilm than ATCC27853 and NCTC6749. They were isolated from bovine mastitis (3/4) and from the healthy bovine $(3 / 15 ; 20 \%)$. Considering place of isolation of strains tested, we demonstrated that the highest amounts of biofilm formed strains isolated from bovine environment (average 0.153). The strains isolated from faeces of healthy bovine, faeces of human and hospital sink formed moderate biofilms (the average $\mathrm{A}=0.125$, $\mathrm{A}=0.131, \mathrm{~A}=0.125$, in particularly) and the strains isolated from bovine mastitis formed a weak biofilm (the average $\mathrm{A}=0.103$ ).

Furthermore, these isolates were also tested for biofilm formation on Tiemann's polyvinylchloride catheter surface. The dynamics and trend of biofilm formation on this surface were identical to those observed with polystyrene microtiter dish method (Table 1). 
Table 1. ERIC-PCR typing, twitching and swimming motility, production of slime, and formation of biofilm of Pseudomonas aeruginosa strains.

\begin{tabular}{|c|c|c|c|c|c|c|c|c|c|c|}
\hline \multirow{3}{*}{ Isolates } & \multirow{3}{*}{$\begin{array}{c}\text { Derivation } \\
\text { of strains }\end{array}$} & \multirow{3}{*}{$\begin{array}{l}\text { ERIC- } \\
\text { PCR } \\
\text { typing }\end{array}$} & \multirow{3}{*}{$\begin{array}{l}\text { Twitching } \\
\text { motility } \\
(\mathrm{mm})\end{array}$} & \multirow{3}{*}{$\begin{array}{l}\text { Swimming } \\
\text { motility } \\
(\mathrm{mm})\end{array}$} & \multirow{3}{*}{ Slime } & \multicolumn{5}{|c|}{ Biofilm to } \\
\hline & & & & & & \multirow{2}{*}{$\begin{array}{c}\text { Microtitrate } \\
\text { plate } 24 \mathrm{~h} \\
(\mathrm{~A} 450 \mathrm{~nm})\end{array}$} & \multicolumn{4}{|c|}{ Tiemann catheter } \\
\hline & & & & & & & $1 \mathrm{~h}$ & $2 \mathrm{~h}$ & $5 \mathrm{~h}$ & $24 \mathrm{~h}$ \\
\hline $3 \mathrm{~V}$ & faeces & 1 & 20 & 17 & - & 0.136 & - & $1+$ & $1+$ & $2+$ \\
\hline $4 \mathrm{~V}$ & faeces & 2 & 23 & 20 & - & 0.200 & $1+$ & $1+$ & $2+$ & $3+$ \\
\hline $5 \mathrm{~V}$ & faeces & 3 & 26 & 20 & $1+$ & 0.129 & $1+$ & $1+$ & $2+$ & $2+$ \\
\hline $6 \mathrm{~V}$ & faeces & 4 & 20 & 10 & $3+$ & 0.091 & - & - & $1+$ & $1+$ \\
\hline $7 \mathrm{~V}$ & faeces & 5 & 25 & 25 & - & 0.217 & $1+$ & $1+$ & $3+$ & $3+$ \\
\hline $8 \mathrm{~V}$ & faeces & 5 & 21 & 22 & - & 0.118 & - & - & $1+$ & $2+$ \\
\hline $9 \mathrm{~V}$ & faeces & 6 & 20 & 20 & $1+$ & 0.103 & - & - & $1+$ & $2+$ \\
\hline $10 \mathrm{~V}$ & faeces & 7 & 20 & 12 & $1+$ & 0.107 & - & - & - & $1+$ \\
\hline $12 \mathrm{~V}$ & faeces & 8 & 22 & 17 & $1+$ & 0.123 & - & $1+$ & $2+$ & $2+$ \\
\hline $13 \mathrm{~V}$ & faeces & 9 & 11 & 12 & $2+$ & 0.080 & - & - & $1+$ & $2+$ \\
\hline $16 \mathrm{~V}$ & faeces & 10 & 12 & 15 & - & 0.150 & - & - & $1+$ & $2+$ \\
\hline $17 \mathrm{~V}$ & faeces & 11 & 20 & 20 & - & 0.113 & - & - & $1+$ & $2+$ \\
\hline $18 \mathrm{~V}$ & faeces & 12 & 20 & 18 & - & 0.106 & - & $1+$ & $1+$ & $2+$ \\
\hline $20 \mathrm{~V}$ & faeces & 13 & 18 & 16 & - & 0.098 & - & - & $1+$ & $2+$ \\
\hline $21 \mathrm{~V}$ & faeces & 14 & 15 & 17 & $1+$ & 0.107 & - & - & $1+$ & $2+$ \\
\hline $11 \mathrm{~V}$ & milk & 15 & 8 & 15 & $1+$ & 0.098 & - & - & $1+$ & $2+$ \\
\hline $19 \mathrm{~V}$ & milk & 16 & 12 & 17 & - & 0.120 & - & - & - & $1+$ \\
\hline $28 \mathrm{~V}$ & milk & 17 & 6 & 10 & $1+$ & 0.096 & - & - & - & $1+$ \\
\hline $22 \mathrm{~V}$ & milk & 14 & 16 & 12 & - & 0.098 & - & - & - & $1+$ \\
\hline $1 \mathrm{EV}$ & litter & 18 & 28 & 25 & - & 0.124 & - & $1+$ & $1+$ & $2+$ \\
\hline $2 \mathrm{EV}$ & litter & 19 & 30 & 22 & - & 0.205 & $1+$ & $1+$ & $2+$ & $3+$ \\
\hline $14 \mathrm{EV}$ & straw & 20 & 28 & 20 & - & 0.130 & - & - & $1+$ & $2+$ \\
\hline $23 \mathrm{H}$ & faeces & 21 & 28 & 24 & $1+$ & 0.128 & $1+$ & $1+$ & $2+$ & $2+$ \\
\hline $24 \mathrm{H}$ & faeces & 21 & 25 & 20 & $1+$ & 0.117 & - & - & $1+$ & $2+$ \\
\hline $25 \mathrm{H}$ & faeces & 22 & 29 & 25 & $1+$ & 0.165 & $1+$ & $1+$ & $2+$ & $3+$ \\
\hline $26 \mathrm{H}$ & faeces & 23 & 19 & 20 & $1+$ & 0.120 & - & - & $1+$ & $2+$ \\
\hline $27 \mathrm{H}$ & faeces & 24 & 25 & 17 & $1+$ & 0.124 & - & - & $1+$ & $2+$ \\
\hline $15 \mathrm{EH}$ & $\operatorname{sink}$ & 25 & 20 & 24 & $1+$ & 0.125 & $1+$ & $1+$ & $2+$ & $2+$ \\
\hline Total & 28 strains & $\begin{array}{l}12 \text { of } \\
\text { types }\end{array}$ & $\begin{array}{c}20.25 \pm \\
6.24\end{array}$ & $\begin{array}{c}18.3 \pm \\
4.39\end{array}$ & $\begin{array}{c}13(1+), \\
46,4 \% \\
1(2+)- \\
3.6 \% \\
1(3+)- \\
3.6 \% \\
13(-)- \\
46.4 \%\end{array}$ & $\begin{array}{c}0.126 \pm \\
0.03\end{array}$ & $\begin{array}{c}7(1+)- \\
25 \% \\
21(-)- \\
75 \%\end{array}$ & $\begin{array}{c}11(1+)- \\
39.3 \% \\
17(-)- \\
60.7 \%\end{array}$ & $\begin{array}{c}16(1+)- \\
57.1 \% \\
7(2+)- \\
25 \% \\
1(3+)- \\
3.6 \% \\
4(-)- \\
14.3 \%\end{array}$ & $\begin{array}{c}5(1+)- \\
17.8 \% \\
19(2+)- \\
67.9 \\
4(3+)- \\
14.3 \%\end{array}$ \\
\hline \multicolumn{2}{|c|}{ NCTC 6749} & $\mathrm{nt}$ & 15 & 12 & $1+$ & 0.116 & - & - & $1+$ & $2+$ \\
\hline \multicolumn{2}{|c|}{ ATCC 27853} & $\mathrm{nt}$ & 17 & 14 & $1+$ & 0.120 & - & - & $1+$ & $2+$ \\
\hline
\end{tabular}

V - veterinary strains, $\mathrm{H}$ - human strains, EV - environmental veterinary, EH - environmental human, (-) - negative result 


\section{Swimming and twitching motility}

The formation of biofilms is a multistep process that requires participation of structural appendages, such as flagella and type IV pili. Variations in biofilm formation, as presented in Table 1 could be due to altered activities of these structural appendages. To test this, we measured the motility and twitching abilities of the isolates, the results of investigation are presented in Table 1. The flagellum activity of 28 of $P$. aeruginosa strains ranged from 10.00 to $25.0 \mathrm{~mm}$. The overall mean value was $18.3 \mathrm{~mm}$ with a standard deviation of 4.39. Half of the studied strains demonstrated higher activity of swimming motility, among them $6(40.0 \%)$ of the strains isolated from faeces of healthy bovine, $3(100 \%)$ of the strains from bovine environment, $5(100 \%)$ of the strains isolated from faeces of hospital patients and one strain isolated from hospital sink. To facilitate comparison of the results obtained we included also reference strains $P$. aeruginosa NCTC 6749 and ATCC 27853 and determined their swimming motility activity to be $12 \mathrm{~mm}$ and $14 \mathrm{~mm}$, respectively. In our study the majority $(23 / 28,82.1 \%$ isolates) of isolates exhibited better swimming motility activity than the reference $P$. aeruginosa strains NCTC 6749 and ATCC 27853.

The quantitative correlation between swimming motility and biofilm production was tested among isolates $(\mathrm{r}=0.59, \mathrm{p}<0.05)$.

Twitching was also visible in all samples, however the isolates varied greatly in their activity. As shown in Table 1, the twitching activity of the reference strains NCTC 6749 and ATCC 27853 was smaller (15 and 17 $\mathrm{mm}$, respectively) as compared to that of the studied strains (faeces of healthy bovine $-19.5 \mathrm{~mm}$, faeces of hospital patients $-25.2 \mathrm{~mm}$, hospital sink $-20 \mathrm{~mm}$, bovine environment $-28.7 \mathrm{~mm}$ ) without strains isolated from bovine mastitis $(10.5 \mathrm{~mm})$.

Isolates forming more biofilm coupled with increased twitching activity. Thus, the quantitative correlation was seen between twitching and biofilm formation $(\mathrm{r}=0.53, \mathrm{p}<0.05)$.

\section{Slime production}

Mucoidy is an important virulence factor in chronic $P$. aeruginosa infections. As seen in Table 1 , the slime producers (15/28, $53.6 \%$ isolates), $46.7 \%$ of the strains isolated from faeces of healthy bovine, $50 \%$ of the strains isolated from bovine mastitis, $100 \%$ of the strains isolated from faeces of human, the strain from hospital sink and references strains NCTC 6749 and ATCC 27853, did not lead to the largest amounts of biofilm formed in this study (the average $\mathrm{A}=0.114$ ).
Conversely strains without slime production (13/28, $46.4 \%$ ) generated higher amounts of biofilms (the average $\mathrm{A}=0.140$ ). Therefore, a negative correlation was seen between slime production and initial biofilm production $(-0.44, \mathrm{p}<0.05)$.

\section{Discussion}

$P$. aeruginosa is an ubiquitous environmental bacterium that is capable of infecting humans, a wide variety of animals and plants. Source of infection or colonization remains to be environment (Head and $\mathrm{Yu}$ 2004). The first stage of the infection is adherence, which can initiate the formation of biofilm (Deziel et al. 2001).

Bacterial adhesion and biofilm formation is a complex process. A study by O;Toole and Kolter (1998) revealed that type IV pili and flagella mediated motility in $P$. aeruginosa was required for biofilm formation on biotic and abiotic surfaces. In our study, we report that all the tested strains demonstrated swimming and twitching activities, the overall mean value was $18.3 \mathrm{~mm}$ and $20.25 \mathrm{~mm}$, respectively. The vast majority of isolates exhibited better twitching and swimming motility than $P$. aeruginosa NCTC 6749 and $P$. aeruginosa ATCC 27853. The strains with great motility activity (isolated from faeces of healthy bovine, hospital patients and bovine environment) showed a higher biofilm-forming ability to polystyrene and polyvinylchloride surfaces. Similarly, in previous study (Wolska and Kot 2013), we found a correlation between biofilm production and twitching motility activity of clinical $P$. aeruginosa strains with the mean value of motility of $24.4 \mathrm{~mm}$.

Such a relationship is not found, when taken into account the production of slime by the strains. Probably, the extracellular matrix including alginate is not required for the initial phase of biofilm formation by P. aeruginosa (Doig et al. 1987).

Our data support the results of other authors, who have indicated that there is no clear line between clinical and environmental strains. Kus et al. (2004) reported that over $71 \%$ of non-CF rectal and clinical isolates and $95.8 \%$ environmental isolates exhibited twitching motility. The high prevalence of twitching motility observed amongst keratitis isolates in comparison to other clinical isolates (Kus et al. 2004) supports the notion that such activity is a requirement for successful $P$. aeruginosa corneal pathogens. Also Woods et al. (1997) were not able to differentiate both clinical and environment isolates on the basis of correlation of production of extracellular enzymes and LD50. While the results of Kumar et al. (2009) indicate that pathogenicity potential of $P$. aeruginosa 
varies depending on the source of strain. Despite similar abilities of biofilm formation and production of quorum sensing signal molecules by environmental and clinical isolates, clinical $P$. aeruginosa isolates were found to have selective advantage in establishing and causing pathology in the urinary tract of mice. Different in vitro biofilm forming capacities and reduced ability of lung colonization was observed in environmental isolates as compared to those exhibited by clinical isolates by Head and Yu (2004). Similarly, Sela et al. (2007) displayed a wide heterogeneity in capacity to form biofilm among $P$. aeruginosa strains isolated from mastitis outbreaks.

To improved our understanding of the genetic link between $P$. aeruginosa isolates, we studied $28 P$. aeruginosa strains isolated from different ecological origins. The relationship between isolates was calculated by numerical analysis of genetic features determined by ERIC-PCR. This molecular genotyping is much faster and more cost-effective; furthermore, it possesses a higher discriminatory ability than other typing techniques (Wolska and Szweda 2012). ERIC-PCR was used successfully, for example, for typing of clinical $P$. aeruginosa (Wolska and Szweda 2008) and to determine the link between pathogenic and non-pathogenic isolates (Yang et al. 2005).

Our study has suggested that there is low level of correlation between $P$. aeruginosa strains isolated from healthy bovine and bovine environment as well as strains isolated from hospital patients. Interesting, thought, is that the two strains, one isolated from faeces of healthy cattle, and the second strain isolated from a case of mastitis, were identical to the basis of dendrogram. This is to confirm that the source of infection of the mammary gland in cattle may be endogenous microflora of the gastrointestinal tract.

Similar results were obtained by Hamouda et al. (2008), who demonstrated high genetic diversity of $P$. aeruginosa strains isolated from food-producing animals and those of clinical origin. However, other authors observed some relationship between clinical and environmental strains. Typing of 18 human and animal (bovine, calves, chicken) isolates by random amplified polymorphic DNA and amplified fragment length polymorphism analysis Osman and colleagues (2010) indicated the similar groups. Romling et al. (1994) demonstrated that $19 \%$ of $P$. aeruginosa strains isolated from various clinical cases and from the aquatic habitats were found to belong to the same clonal group. Similar homogeneity was found among $P$. aeruginosa strains isolated from cases of either clinical infection and from gasoline sources (Foght et al. 1996).

The genetic studies of strains isolated from cows with mastitis and strains isolated from clinical infec- tions in humans have not confirmed the close relationship of these microorganisms. However, the use of one or a few strains to represent animal, human and environment habitat may have limited the conclusion of these studies. Similar results were obtained by Daly et al. (1999). Thirty six isolates $P$. aeruginosa from mastitis outbreaks were tested and compared to fourteen clinical isolates. Eight of the clinical isolates gave the same Clal ribotype pattern as the mastitis-causing strains. However, PwuII proved more discriminatory, with only the outbreak isolates producing identical pattern. Similar results were obtained with RW3A-primed DNA amplification fingerprinting, with all outbreak isolates except one displaying the same fingerprint array. The clinical strains produced several fingerprint patterns, all of which were different from those of the mastitis-causing isolates (Daly et al. 1999).

In conclusion, the genetic relationship among the groups of $P$. aeruginosa strains tested here showed that neither healthy and sick bovine nor hospital patients and environment was caused by specific genotypes within this species. The evolution of $P$. aeruginosa strains has not allowed the establishment of a clear phylogenetic separation between pathogenic and non-pathogenic strains.

\section{References}

Christensen GD, Simpson WA, Bisno AL, Beachey EH (1982) Adherence of slime-producing strains of Staphylococcus epidermidis to smooth surfaces. Infect Immun 37: 318-326.

Daly M, Power E, Björkroth J, Sheehan P, O'Connell A, Colgan M, Korkeala H, Fanning S (1999) Molecular analysis of Pseudomonas aeruginosa: epidemiological investigation of mastitis outbreaks in Irish dairy herds. Appl Environ Microbiol 65: 2723-2729.

Deziel E, Comeau Y, Villemur R (2001) Initiation of biofilm formation by Pseudomonas aeruginosa 57RP correlates with emergence of hyperpiliated and highly adherent phenotypic variants deficient in swimming, swarming, and twitching motilities. J Bacteriol 183: 1195-1204.

Doig P, Smith NR, Todd T, Irvin RT (1987) Characterization of the binding of Pseudomonas aeruginosa alginate to human epithelial cells. Infect Immun 55: 1517-1522.

Erskine RJ, Unflat JG, Eberhart RJ, Hutchinson LJ, Hicks CR, Spencer SB (1987) Pseudomonas mastitis: difficulties in detection and elimination from contaminated wash-water systems. J Am Vet Med Assoc 191: 811-815.

Foght JM, Westlake DWS, Johnson WM, Ridgway HF (1996) Environmental gasoline-utilizing isolates and clinical isolates of Pseudomonas aeruginosa are taxonomically indistinguishable by chemotaxonomic and molecular techniques. Microbiology 142: 2333-2340.

Glessner A, Smith RS, Iglewski BH, Robinson JB (1999) Roles of Pseudomonas aeruginosa las and rhl 
quorum-sensing systems in control of twitching motility. J Bacteriol 181: 1623-1629.

Hamouda A, Vali L, Amyes SGB (2008) Gram-negative non-fermenting bacteria from food-producing animals are low risk for hospital-acquired infections. J Chemother 20: 702-708.

Head NE, Yu H (2004) Cross-sectional analysis of clinical and environmental isolates of Pseudomonas aeruginosa: biofilm formation, virulence, and genome diversity. Infect Immun 72: 133-144.

Hentzer M, Teitzel GM, Balzer GJ, Heydorn A, Molin S, Givskov M, Parsek MR (2001) Alginate overproduction affects Pseudomonas aeruginosa biofilm structure and function. J Bacteriol 183: 5395-5401.

Hulton CS, Higgins CF, Sharp PM (1991) ERIC sequences: a novel family of repetitive elements in the genomes of Escherichia coli, Salmonella typhimurium and other enterobacteria. Mol Microbiol 5: 825-834.

Kingsford NM, Raadsma HW (1995) Detection of Pseudomonas aeruginosa from ovine fleece washings by PCR amplication of 16S ribosomal RNA. Vet Microbiol 47: 61-70.

Klausen M, Heydorn A, Ragas P, Lambertsen L, Aaes-Jrrgensen A, Molin S, Tolker-Nielsen T (2003) Biofilm formation by Pseudomonas aeruginosa wild type, flagella and type IV pili mutants. Mol Microbiol 48: 1511-1524.

Kumar R, Chhibber S, Harjai K (2009) A comparative study of clinical and environmental isolates of Pseudomonas aeruginosa in terms of quorum sensing, outer membrane proteins and their ability to cause urinary track infection. Am J Biomed Sci 1: 205-214.

Kus JV, Tullis E, Cvitkovitch DG, Burrows LL (2004) Significant differences in type IV pilin allele distribution among Pseudomonas aeruginosa isolates from cystic fibrosis (CF) versus non-CF patients. Microbiology 150: 1315-1326.

Malinowski E, Lassa H, Kłossowska A, Smulski S, Markiewicz H, Kaczmarowski M (2006) Etiological agents of dairy cows' mastitis in western part of Poland. Pol J Vet Sci 9: 191-194.

McLennan MW, Kelly WR, O'Boyle D (1997) Pseudomonas mastitis in a dairy herd. Aust Vet J 75: 790-792.

Osman KM, Alabady MS, Ata NS, Ezzeldin NA, Aly MA (2010) Genotypic characterization of Pseudomonas aeruginosa isolated from human and animals sources in Egypt. Zoonoses Public Health 57: 329-338.

O’Toole GA, Kolter R (1998) Flagellar and twitching motility are necessary for Pseudomonas aeruginosa biofilm development. Mol Microbiol 30: 295-304.
Prosser BL, Taylor D, Dix BA, Cleeland R (1987) Method of evaluating effects of antibiotics on bacterial biofilm. Antimicrob Agents Chemother 31: 1502-1506.

Römling U, Wingender J, Muller H, Tummler B (1994) A major Pseudomonas aeruginosa clone common to patients and aquatic habitats. Appl Environ Microbiol 60: 1734-1738.

Sauer K, Camper AK, Ehrlich GD, Costerton JW, Davies DG (2002) Pseudomonas aeruginosa displays multiple phenotypes during development as a biofilm. J Bacteriol 184: $1140-1154$.

Sela S, Hammer-Muntz O, Krifucks O, Pinto R, Weisblit L, Leitner G (2007) Phenotypic and genotypic characterization of Pseudomonas aeruginosa strains isolated from mastitis outbreaks in dairy herds. J Dairy Res 74: 425-429.

Singh PK, Schaefer AL, Parsek MR, Moninger TO, Welsh MJ, Greenberg EP (2000) Quorum-sensing signals indicate that cystic fibrosis lungs are infected with bacterial biofilms. Nature 407: 762-764.

Skerker JM, Berg HC (2001) Direct observation of extension and retraction of type IV pili. Proc Natl Acad Sci USA 98: 6901-6904.

Versalovic J, Koeuth T, Lupski JR (1991) Distribution of repetitive DNA sequences in eubacteria and application to fingerprinting of bacterial genomes. Nucleic Acids Res 19: 6823-6831.

Wolska K, Szweda P (2008) A comparative evaluation of PCR ribotyping and ERIC PCR for determining the diversity of clinical Pseudomonas aeruginosa isolates. Pol J Microbiol 57: 157-163.

Wolska K, Szweda P (2012) Genotyping techniques for determining the diversity of microorganisms. In: Caliskan M (ed) Genetic diversity in microorganisms. In Tech, Croatia, pp 53-94.

Wolska K, Kot B (2013) Twitching motility activity, biofilm formation, and genetic typing for clinical isolates of Pseudomonas aeruginosa by random amplified DNA PCR. Acta Microbiol Immunol Hung 60: 313-328.

Woods DE Lam JS, Paranchych W, Speert DP, Campbell M, Godfrey AJ (1997) Correlation of Pseudomonas aeruginosa virulence factors from clinical and environmental isolates with pathogenicity in the neutropenic mouse. Can J Microbiol 43: 541-551.

Yang W, Shi L, Jia WX, Yin X, Su JY, Kou Y, Yi X, Shinoda S, Miyoshi $S$ (2005) Evaluation of the biofilm-forming ability and genetic typing for clinical isolates of Pseudomonas aeruginosa by enterobacterial repetitive intergenic consensus-based PCR. Microbiol Immunol 49: 1057-1061. 